Research paper

\title{
Effects of burn season on large seedlings of oak and other hardwood regeneration three years after shelterwood harvest
}

\author{
Ying Xin ${ }^{1}$ and Roger A. Williams ${ }^{2, *}$
}

Xin, Y., Williams, R.A. 2019. Effects of burn season on large seedlings of oak and other hardwood regeneration three years after shelterwood harvest. - Forestry Studies | Metsanduslikud Uurimused 71, 1-16, ISSN 1406-9954. Journal homepage: http://mi.emu.ee/forestry. studies

\begin{abstract}
The effects of fall and spring prescribed fires on large seedlings ( 0.3 to $1.3 \mathrm{~m}$ height) of oak and other hardwood species three years after a shelterwood harvest were examined in Richland Furnace and Zaleski State Forests in southern Ohio. Fall and spring burns appeared to be more deleterious to red oaks (Quercus rubra L., Q. velutina Lam., Q. coccinea Muenchh.) than white oaks (Q. alba L., Q. prinus L.). Red oak experienced reductions in numbers and canopy volume after spring burns, and canopy reductions after fall burns. White oak experienced small increases in numbers of stems after both fall and spring burns, and an increase in the canopy volume after fall burns, but a slight decrease after spring burns. Yellow-poplar (Liriodendron tulipifera L.), a major oak competitor prior to fire, experienced dramatic reductions in the number of regenerating stems and canopy volume after both fall and spring burns. On the other hand, red maple (Acer rubrum L.) experienced large increases in the number of regenerating stems and canopy volume after both fall and spring burns. Based on importance value, the oak species remained relatively unchanged after both fall and spring burns. Yellow-poplar became the least dominant species after spring burns and the second to last dominant species after fall burns.
\end{abstract}

Key words: prescribed fire, burn season, seedling, regeneration, shelterwood harvest.

Authors' addresses: ${ }^{1}$ College of Engineering \& Technology, Northeast Forestry University, Harbin, Heilongjiang 150040, China; ${ }^{2}$ School of Environment and Natural Resources, The Ohio State University, Columbus, Ohio 43210, USA; *email: williams.1577@osu.edu

\section{Introduction}

Throughout the history of eastern North America, oak (Quercus spp.) has dominated many of the forests and woodlands (Delcourt \& Delcourt, 1987; McShea \& Healy, 2002). However, regenerating oak stands, particularly on productive sites, have been an important problem for resource managers (Lorimer et al., 1994; Brose et al., 1999). It is difficult to get and keep the oak in a dominant position in the forest partly due to the species' slow growth and shade intolerance. Oak's capacity to regenerate itself is limited, especially in high-density forests. Without any type of disturbance 
that would reduce the amount of forest canopy, oak succumbs to more shade-tolerant species, such as red maple (Acer rubrum L.), American beech (Fagus grandifolia Ehrh.) and sugar maple (Acer saccharum Marsh.). Shade-tolerant species therefore become well-established in the midstory and understory in the absence of disturbance, slowly replacing and dominating oaks in the overstory (Abrams \& Downs, 1990). This problem has been exacerbated by fire exclusion policies in the U.S. over many decades in the past (Abrams, 1992; Lorimer, 1993; Van Lear \& Brose, 2002).

Fire within ecosystem communities often creates opportunities for seed germination and seedling establishment (Glasgow \& Matlack, 2007), especially in fire-dependent communities such as oak forests. Prescribed fire has been used to regenerate oak-dominated stands and improve the sustainability of oak forests (McShea \& Healy, 2002). Fire can increase the regeneration potential of oak through three different mechanisms: (1) reduce the tree shade by opening up the canopy, which allows shade-intolerant oak to develop the size and mass of their root system; (2) control competition from more fire-sensitive species in the understory (Hutchinson et al., 2005); and (3) improve more favorable microsite conditions for germination and seedling establishment (Hoffmann, 1996; D'Antonio et al., 2001).

Because red maple, yellow poplar (Liriodendron tulipifera L.) and oak occupy many sites together in the reproduction layer, competition exists among them. When oak exists with its competitors, which often are higher numbers of shade-tolerant (fire-sensitive) trees, it displays slow growth (Steinhoff, 1978). Shade-tolerant species can make significant height growth and increase both in number and size steadily under a closed canopy, and thus have an important advantage over oaks (Loftis \& McGee, 1993).

The composition of a fire-prone ecosystem is influenced by fire frequency, intensi- ty and the time of year, or season, when fire occurs (Bradstock \& Cohn, 2002). Season affects seedling regeneration because of: (1) the interaction of season with the temperature requirements for seed germination and growth; (2) the interaction of the different post-fire regeneration conditions and the competition of surrounding species; and (3) the rainfall and temperature effects on seedling regeneration (Knox \& Clarke, 2006). Many studies have focused on the effects of fire season on seedling emergence and survival (Hodgkinson, 1991; Sparks et al., 1998; Konstantinidis et al., 2005). The season of fire influences the amount of heat infiltrating the soil, which in turn affects soil moisture. The different seasons also influence fuel moisture and therefore fire intensity. Differences in metabolism and physiological processes between species will likewise create different responses as a result of the different burn seasons.

In this paper, we monitored the changes in the mean number of large and small seedling stems and the mean crown volume of large seedlings of hardwood regeneration one year before and after prescribed fire in oak-hickory forests. The prescribed burns were implemented three years after a shelterwood harvest was conducted in the forests, and burns were conducted in fall and spring seasons. Therefore, the objectives are to: (1) examine the effects of burn season on oak regeneration; (2) examine how the canopy of large seedlings respond to prescribed fire and thus indicate a level of competition; and (3) determine whether fire could improve the competitiveness of oak by analyzing the seedling canopy. This knowledge will help provide a better understanding of the seedling dynamics following fire.

\section{Methods}

\section{Site and treatment descriptions}

This study was conducted in Richland Furnace State Forest (RFSF; $39.171^{\circ} \mathrm{N}$, 
$\left.82.602^{\circ} \mathrm{W}\right)$ and Zaleski State Forest (ZSF; $\left.39.334^{\circ} \mathrm{N}, 82.311^{\circ} \mathrm{W}\right)$ in southern Ohio. Both forests lie within the unglaciated Allegheny Plateau Region which is extensively dissected by watershed drains that exhibit undulating and rough topography. Elevation within the region ranges from the lowest point of $180 \mathrm{~m}$ to the highest point of 320 $\mathrm{m}$ above sea level. The total annual precipitation is $104 \mathrm{~cm}$, with over half of this precipitation occurring from April through September. The forests were dominated by oak and mixed hardwood species (Table 1).

Table 1. The species present in the overstory prior to harvest in the Richland Furnace State Forest and Zaleski State Forest, southern Ohio.

\begin{tabular}{llll}
\hline Upland Oak & Mixed Hardwoods & Understory & Hickory \\
\hline Quercus alba L. & Acer saccharum Marsh. & Amelanchierspp. & Carya glabra (Mill.) \\
Quercus coccinea & Acer rubrum L. & Carpinus caroliniana & Carya laciniosa \\
Muenchh. & Fagus grandifolia Ehrh. & Walt. & (Michx. f.) Lould. \\
Quercus prinus L. & Fraxinus americana L. & Corylus americana Marsh. & Carya tomentosa \\
Quercus rubra L. & Fraxinus pennsylvanica & Hamamelis virginiana L. & (Poir.) Nutt. \\
Quercus velutina Lam. & Marsh. & Lindera benzoin L. & \\
& Liriodendron tulipifera L. & Ostrya virginiana (Mill.) \\
& Nyssa sylvatica Marsh. & K. Koch & \\
& Populus grandidentata & Sassafras albidum (Nutt.) \\
& Michx. & Nees & \\
& Prunus serotina Ehrh. & Viburnum spp. & \\
& Ulmus americana L. & & \\
& Ulmus rubra Muhl. & & \\
& &
\end{tabular}

In 2005 , four 10 ha treatment blocks were established in each forest to study the effects of shelterwood harvests and prescribed fire on oak and other hardwood regeneration. Two treatment blocks in each forest were established to study a fall burn three years after the shelterwood harvest and the other two blocks to study a spring burn. Plot measurements were initially taken in 2005 prior to harvests. Prior to harvest the basal area averaged $29.9 \mathrm{~m}^{2}$ ha $^{-1}$ with 351 trees ha-1 in RFSF, with oak and hickory accounting for 84 percent of the basal area. In ZSF, the basal area averaged $24.0 \mathrm{~m}^{2} \mathrm{ha}^{-1}$ with 328 trees ha-1, with oak and hickory accounting for 87 percent of the basal area. In 2006, the forests were thinned to approximately 50\% stocking based on percent stocking determined by using stocking charts for upland hardwoods (Williams, 2003) and were still at $50 \%$ stocking at the time burns were initiated three years later (Table 2).
Table 2. Forest attributes in Richland Furnace State Forest and Zaleski State Forest in southern Ohio before and after prescribed burns. Dbh - diameter at breast height.

\begin{tabular}{|c|c|c|c|c|c|}
\hline $\begin{array}{l}\text { Time } \\
\text { period }\end{array}$ & Forest & $\begin{array}{c}\text { Basal area } \\
\left(\mathrm{m}^{2} \mathrm{ha}^{-1}\right)\end{array}$ & $\begin{array}{l}\begin{array}{l}\text { Trees } \\
\left(\mathrm{ha}^{-1}\right)\end{array} \\
\end{array}$ & $\begin{array}{l}\text { Dbh } \\
(\mathrm{cm})\end{array}$ & $\begin{array}{c}\text { Stocking } \\
(\%)\end{array}$ \\
\hline \multirow[t]{2}{*}{$\begin{array}{l}\text { Before } \\
\text { burn }\end{array}$} & $\begin{array}{l}\text { Rich. } \\
\text { Furn. } \\
\text { SF }\end{array}$ & 15.6 & 106 & 43.4 & 52 \\
\hline & $\begin{array}{l}\text { Zaleski } \\
\text { SF }\end{array}$ & 15.9 & 129 & 37.1 & 54 \\
\hline \multirow[t]{2}{*}{$\begin{array}{l}\text { After } \\
\text { burn }\end{array}$} & $\begin{array}{l}\text { Rich. } \\
\text { Furn. } \\
\text { SF }\end{array}$ & 12.0 & 101 & 37.2 & 41 \\
\hline & $\begin{array}{l}\text { Zaleski } \\
\text { SF }\end{array}$ & 9.6 & 120 & 28.1 & 34 \\
\hline
\end{tabular}

Prescribed burns were implemented during the fall of 2009 and spring of 2010. Half of the treatment areas were burned on November 11, 2009 in both forests, and the remaining treatment areas in both forests were burned on March 30, 2010. Plot 
measurements were taken during the late summer of 2009 prior to all burns and final measurements were taken during the late summer of 2010, allowing one growing season to occur following the burns. The burns were conducted on the same day in each forest in both the fall and spring to minimize variations of weather conditions during the burns. The burn firing methods were the same in all burns, using drip torches as the ignition source and a combined technique of ring firing and strip head firing to place the fire within the treatment areas.

\section{Plot establishment and measurements}

Each shelterwood treatment block encompassed 10 ha and was replicated four times in each forest, with two shelterwood treatments in each forest receiving fall burns and two receiving spring burns. Eight permanent circular 0.08 ha overstory plots were located within each treatment block, using a systematic scheme rather than a random approach so that plots would be evenly distributed over each treatment block. This created 32 plots in each forest for a total of 64 plots. Plots were established in 2005 prior to the shelterwood harvests, and re-measured in 2006 after harvest, again in 2007, in 2009 prior to burning and in 2010 after the burns.

On the permanent circular 0.08 ha overstory plots, all trees $>10 \mathrm{~cm}$ from diameter at breast height (dbh) were measured and recorded by species. A circular secondary plot 0.04 ha in size was circumscribed about the same plot center as the overstory plot for the purpose of measuring saplings $(1.3 \mathrm{~m}$ tall to $\leq 10 \mathrm{~cm} \mathrm{dbh})$. A circular tertiary plot 0.02 ha in size was also circumscribed about the same plot center as the overstory plot in order to measure large seedlings (0.3 to $1.3 \mathrm{~m}$ height). Finally, a circular quaternary plot 0.01 ha in size was circumscribed about the same plot center as the overstory plot for the purpose of measuring small seedlings $(<0.3 \mathrm{~m}$ height).
For this paper, data collected from the 0.02 ha large seedling plots were analyzed. On the large seedling plots, the total height, height to live crown, and major and minor axis of the seedling crown of large seedlings was measured and recorded by species to the nearest $0.05 \mathrm{~m}$. However, due to time constraints, only 24 of the original 64 plots established at the outset of the study in 2005 were measured prior to the burns in 2009, accounting for 12 plots in each forest, 6 in each fall and spring burn treatment. The same plots were measured post burn in 2010 to create a series of paired plots.

Crown volume was estimated for large seedlings using the crown length and the quadratic mean of the major and minor axis of the crown. It was assumed that the average crown approximated the shape of a cone (Karlik and McKay, 2002), and the formula:

$$
V=\frac{\pi d^{2} L}{12}
$$

where $V=$ volume in $\mathrm{m}^{3}, d^{2}=$ the average crown diameter $(\mathrm{m})$, and $L=$ crown length $(\mathrm{m})$, was used to estimate the crown volume of each stem. Crown length was determined by subtracting the height to the live crown of the large seedling from its measured total height. A SAS algorithm developed by Avina et al. (2007) to calculate and estimate the total crown volume in different canopy strata from the ground surface up through the main canopy was used to determine the total crown volume $\left(\mathrm{m}^{3} \mathrm{ha}^{-1}\right)$ of large seedlings.

\section{Statistical analysis}

Analysis of variance (ANOVA) was performed on the mean canopy volume per hectare and the number of stems per hectare for large seedlings between species and treatments (burn season). For analysis purposes, species were grouped into categories of interest, which included red oaks (Quercus rubra L., Q. velutina Lam., $Q$. coccinea Muenchh.), white oaks ( $Q$. alba L., $Q$. prinus L.), hickories (Carya glabra (Mill.), 
C. laciniosa (Michx. f.) Lould., C. tomentosa (Poir.) Nutt.), red maple and yellow-poplar. All other species were grouped into the mixed hardwoods group. Duncan's multiple range test was used to test for differences between means at the $p=0.05$ level.

\section{Results}

\section{Large seedlings}

ANOVA revealed that significant differences $(p=0.05)$ existed among species following fall burns in the seedling canopy volume and the number of stems per hectare (Table 3). The fact that no other significant differences were detected may be the result of the relatively low sample size $(n=12$ for fall burns, $n=12$ for spring burns). Duncan's multiple range test was used to determine where those differences occurred among species.

\section{Large seedling canopy volume}

Due to high variances among samples and relatively few sample plots, it was not possible to detect significant differences among samples before and after burns in most cases. We could only detect a significant increase in red maple crown volume after fall burns (Table 4). Mixed hardwoods had significantly more crown volume compared to other species before and after fall burns, and after spring burns. Mixed hardwoods experienced the greatest increase in canopy volume after fall burns, increasing by $286 \%$ (Figure 1 ).

On the fall burn sites, yellow-poplar ac-

Table 3. Analysis of variance statistics for large seedling (0.3-1.3 m total height) canopy volume $\left(\mathrm{m}^{3} \mathrm{ha}^{-1}\right)$ and large seedling stems per hectare within each species group before and after fall and spring burns in Richland Furnace and Zaleski State Forests in southern Ohio.

\begin{tabular}{lllccc}
\hline Attribute & Variable & Source of variation & RMSE & Fvalue & Pr $>$ F \\
\hline Canopy volume & Fall burn & Time relative to burn & 182.01 & 1.99 & 0.1604 \\
& Spring burn & Time relative to burn & 126.23 & 0.01 & 0.9936 \\
& Pre-burn & Burn season & 106.39 & 0.92 & 0.3394 \\
& Post-burn & Burn season & 196.22 & 0.59 & 0.4453 \\
& Fall burn & Pre-burn & 60.14 & 2.14 & 0.0711 \\
& & Post-burn & 234.86 & 2.85 & 0.0217 \\
& Spring burn & Pre-burn & 141.72 & 0.56 & 0.7271 \\
& & Post-burn & 103.81 & 3.03 & 0.0168 \\
\hline Stems per hectare & Fall burn & Time relative to burn & 2646.09 & 2.05 & 0.1541 \\
& Spring burn & Time relative to burn & 2488.14 & 0.22 & 0.6367 \\
& Pre-burn & Burn season & 2325.26 & 0.28 & 0.5969 \\
& Post-burn & Burn season & 2796.71 & 1.79 & 0.1837 \\
& Fall burn & Pre-burn & 2106.04 & 2.18 & 0.0669 \\
& & Post-burn & 2222.38 & 13.25 & $<.0001$ \\
& Spring burn & Pre-burn & 2457.37 & 1.06 & 0.3929 \\
& Post-burn & 2335.16 & 3.06 & 0.0159 \\
\hline
\end{tabular}


Table 4. The mean ${ }^{1}$ (standard deviation) of the total crown volume $\left(\mathrm{m}^{3} \mathrm{ha}^{-1}\right)$ of large seedlings $(0.3-$ $1.3 \mathrm{~m}$ total height) for species group one year before and one year after prescribed fire by burn season (fall vs spring) in Zaleski and Richland Furnace State Forests in southern Ohio.

\begin{tabular}{llclc}
\hline & \multicolumn{2}{c}{ Fall burn } & \multicolumn{2}{c}{ Spring burn } \\
\hline Species & \multicolumn{1}{c}{ Pre-burn } & Post-burn & Pre-burn & Post-burn \\
\hline Red oak & $24.1(21.0) \mathrm{Aa}$ & $20.7(25.3) \mathrm{Aa}$ & $51.4(92.5) \mathrm{Aa}$ & $16.9(17.7) \mathrm{Aa}$ \\
White oak & $23.3(32.7) \mathrm{Aa}$ & $38.3(55.6) \mathrm{Aa}$ & $47.1(108.4) \mathrm{Aa}$ & $43.1(105.5) \mathrm{ABa}$ \\
Hickory & $15.9(19.3) \mathrm{Aa}$ & $6.6(9.0) \mathrm{Aa}$ & $11.2(9.1) \mathrm{Aa}$ & $14.3(14.2) \mathrm{Aa}$ \\
Red maple & $40.2(49.8) \mathrm{ABa}$ & $96.4(70.2) \mathrm{Ab}$ & $50.9(51.0) \mathrm{Aa}$ & $128.0(140) \mathrm{Ba}$ \\
Yellow-poplar & $62.9(119.4) \mathrm{ABa}$ & $32.3(64.9) \mathrm{Aa}$ & $97.7(306.1) \mathrm{Aa}$ & $20.6(80.9) \mathrm{Aa}$ \\
Mixed Hardwoods & $79.9(57.3) \mathrm{Ba}$ & $308.9(194.2) \mathrm{Ba}$ & $92.3(104.8) \mathrm{Aa}$ & $126.6(114.0) \mathrm{Ba}$ \\
\hline
\end{tabular}

${ }^{1}$ Means followed by the same capital letter are not significantly between species within burn season (fall/spring) and time relative to burn (pre-burn/post-burn). Means followed by the same small case letter are not significantly different between time relative to burn within species and burn season, Duncans MRT $(p=0.05)$.

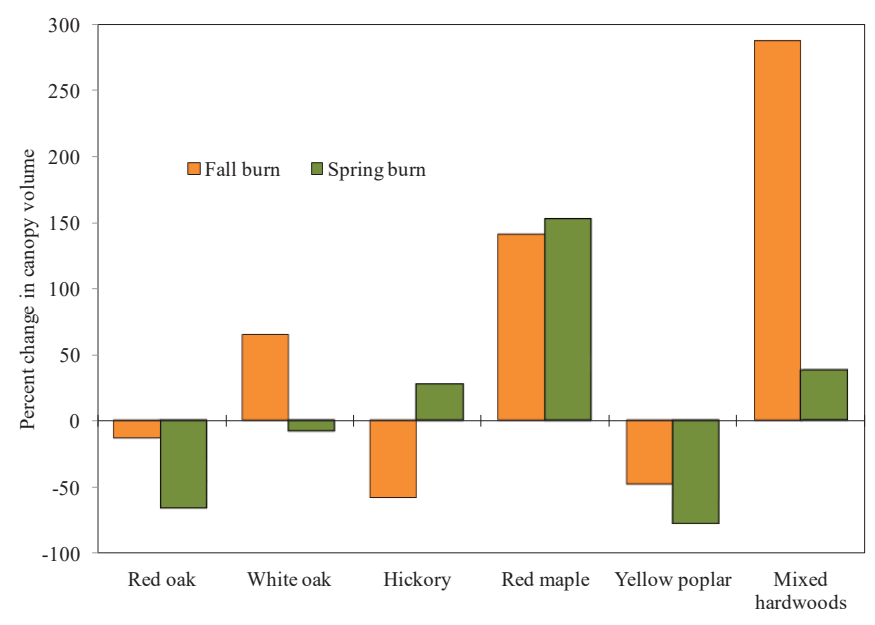

Figure 1. The percent change in large seedling (0.3-1.3 $\mathrm{m}$ total height) canopy volume $\left(\mathrm{m}^{3} \mathrm{ha}^{-1}\right)$ after fall and spring burns in Richland Furnace and Zaleski State Forests of southern Ohio.

counted for $26 \%$ of the total canopy volume, and together with red maple and mixed hardwoods, accounted for $74 \%$ of the total canopy volume prior to burns on the fall burn sites (Table 4). However, after the fall burns, yellow-poplar accounted for only $6 \%$ of the total seedling canopy while red maple and mixed hardwoods combined accounted for $81 \%$ of the total canopy volume.
On the spring burn sites, yellow-poplar accounted for $28 \%$ of the total canopy volume, and combined with red maple and mixed hardwoods accounted for $69 \%$ of the total canopy volume. After the spring burns, yellow-poplar was reduced to $6 \%$ of the total volume while red maple and mixed hardwoods made up $74 \%$ of the total volume. 
Both fall and spring burns reduced the red oak canopy volume, with spring burns reducing the volume by a greater magnitude (Figure 1). Fall burns reduced the red oak canopy by $14 \%$ while spring burns reduced the canopy by $67 \%$ (Table 4 ). Prior to fall burns, red oak comprised $10 \%$ of the total canopy and was reduced to $4 \%$ of the total canopy after the burns. Prior to spring burns the red oak canopy made up $15 \%$ of the total canopy but was reduced to $5 \%$ of the total canopy following the burns.

White oak accounted for 9\% and 13\% of the total canopy prior to burning on the fall burn and spring burn sites, respectively (Table 4). Spring burns reduced the white oak canopy by only $8 \%$, accounting for $12 \%$ of the total canopy following the burns. However, fall burns increased the volume of white canopy by $64 \%$; but because of the increased mixed hardwood and red maple canopy, the white oak seedling canopy occupied a lower percentage of the total seedling canopy than before the burn (Figure 1).

Fall burns resulted in a decrease in hickory canopy volume by $59 \%$ (Figure 1 ). This reduced hickory from $6 \%$ of the total seed- ling canopy to $1 \%$ (Table 4). Spring burns on the other hand increased the hickory canopy volume by $27 \%$. This increase resulted in changing hickory from comprising $3 \%$ of the total seedling canopy prior to the burns, to $4 \%$ of the total seedling canopy after the burns.

\section{Large seedling stems per hectare}

Prior to the burns, significantly more yellow-poplar and mixed hardwood stems occurred on sites where fall burns were to be executed, accounting for $52 \%$ of total stems (Table 5). Yellow-poplar and mixed hardwoods accounted for $25 \%$ and $27 \%$ of total stems, respectively. After fall burns, mixed hardwood stems increased significantly by $141 \%$, and were significantly higher than all other species (Figure 2). Mixed hardwoods accounted for $48 \%$ of total stems after the fall burns. Yellow-poplar on the other hand was reduced by $64 \%$ after the fall burns, comprising $7 \%$ of total stems after the fall burns. Similarly, yellow-poplar was reduced by $61 \%$ after spring burns, thereby decreasing its percent composition of total stems from $19 \%$ prior to spring burns to $7 \%$ of total stems following burns.

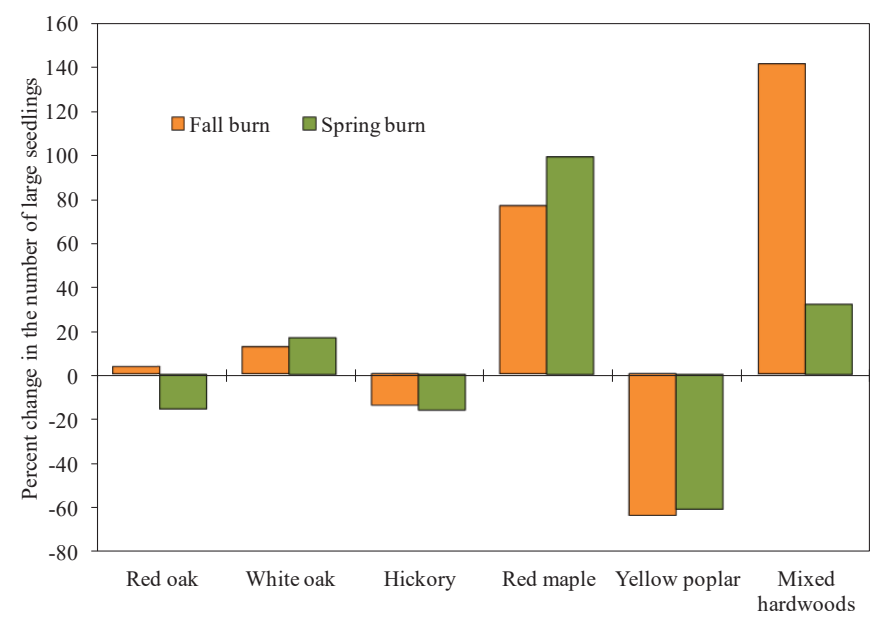

Figure 2. The percent change in the number of large seedling (0.3-1.3 m total height) stems per hectare after fall and spring burns in Richland Furnace and Zaleski State Forests of southern Ohio. 
Table 5. The mean ${ }^{1}$ (standard deviation) of the number (stems per hectare) of large seedlings (0.3-1.3 m total height) for species group one year before and one year after prescribed fire by burn season (fall vs spring) in Zaleski and Richland Furnace State Forests in southern Ohio.

\begin{tabular}{lcccc}
\hline & \multicolumn{2}{c}{ Fall burn } & \multicolumn{2}{c}{ Spring burn } \\
\hline Species & Pre-burn & Post-burn & Pre-burn & Post-burn \\
\hline Red oak & $1334(1039) \mathrm{ABa}$ & $1379(725) \mathrm{ABa}$ & $1334(1137) \mathrm{Aa}$ & $1127(894) \mathrm{ABa}$ \\
White oak & $1503(1451) \mathrm{ABa}$ & $1688(1721) \mathrm{ABa}$ & $1733(2629) \mathrm{Aa}$ & $2021(3185) \mathrm{ABCa}$ \\
Hickory & $325(267) \mathrm{Aa}$ & $280(354) \mathrm{Aa}$ & $373(252) \mathrm{Aa}$ & $314(219) \mathrm{Aa}$ \\
Red maple & $1758(1596) \mathrm{ABa}$ & $3100(2072) \mathrm{Ba}$ & $1302(1251) \mathrm{Aa}$ & $2582(1891) \mathrm{ABCa}$ \\
Yellow-poplar & $2589(3978) \mathrm{Ba}$ & $926(1216) \mathrm{ABa}$ & $1725(4476) \mathrm{Aa}$ & $674(1878) \mathrm{ABa}$ \\
Mixed hardwoods & $2783(1903) \mathrm{Ba}$ & $6710(3566) \mathrm{Cb}$ & $2686(2530) \mathrm{Aa}$ & $3543(3828) \mathrm{Ca}$ \\
\hline
\end{tabular}

${ }^{1}$ Means followed by the same capital letter are not significantly different between species within burn season (fall/spring) and time relative to burn (pre-burn/ post-burn). Means followed by the same small case letter are not significantly different between time relative to burn within species and burn season, Duncans MRT $(p=0.05)$.

Red maple displayed a $76 \%$ increase after the fall burns, accounting for $22 \%$ of total stems after the burns, compared to $17 \%$ before the burns. Spring burns produced a more favorable response of red maple, increasing its numbers by $98 \%$ (Figure 2). Prior to spring burns red maple accounted for $14 \%$ of the total stem composition, which subsequently increased to $25 \%$ of the total composition following the spring burns (Table 5).

Very little change occurred in the number of red oak stems following fall burns, and spring burns reduced the number of stems by $16 \%$ (Figure 2). In spite of the small increase in the number of red oak stems after fall burns, red oak was reduced compared to the total of regenerating stems, dropping from $13 \%$ of total stems before the burns to $10 \%$ after the burns (Table 5).

White oak experienced an increase in the number of stems after both fall and spring burns, increasing by $12 \%$ and $16 \%$, respectively (Figure 2). The increase that occurred after spring burns was enough to raise the number of white oak stems representing the total stems from $19 \%$ to $20 \%$. However, the increase in white oak stems after fall burns was not enough to increase its component of total stems, as it dropped from $14 \%$ of total stems prior to burning to $12 \%$ after burning.

Hickory remained a very small fraction of the total seedling composition before and after fall and spring burns (Table 5). Prior to the burns, hickory accounted for $3 \%$ and $4 \%$ of total stems on the fall and spring burn sites, respectively. Following the burns, these figures dropped to $2 \%$ and $3 \%$ of total stems after fall and spring burns, respectively. Hickory experienced a 3\% increase in stems after fall burns, but displayed a 16\% decrease after spring burns (Figure 2).

\section{Importance value index}

The importance value index (IVI) (Curtis, 1959) of large seedlings for each species group was calculated (Table 5). IVI for a species is typically determined by the average of relative frequency, relative density and relative basal area as an indicator of the amount of area each species occupies relative to other species. However, in this paper, the relative crown volume was used instead of relative basal area as an indicator of occupied space.

Prior to fall and spring burns, yellow-poplar and mixed hardwoods were 
the top two dominant species groups based on IVI (Table 6). Following both fall and spring burns, mixed hardwoods remained as first importance in the seedling population, but yellow-poplar fell to next to last (ahead of hickory) after fall burns, and last after spring burns. Red maple took yellow-poplar's place in dominance following fall and spring burns, behind the mixed hardwoods.

Table 6. The Importance Value Index ${ }^{1}$ for large seedlings $(0.3-1.3 \mathrm{~m}$ total height) by species groups and burn season one year before and after prescribed fire in Zaleski and Richland Furnace State Forests of southern Ohio. The Importance Value Index ranking is indicated in the parenthesis.

\begin{tabular}{llclc}
\hline & \multicolumn{2}{c}{ Fall burn } & \multicolumn{2}{c}{ Spring burn } \\
\hline Species group & Pre-burn & Post-burn & Pre-burn & Post-burn \\
\hline Red oak & $115.1(5)$ & $113.9(4)$ & $111.1(4)$ & $115.8(4)$ \\
White oak & $116.4(4)$ & $119.6(3)$ & $114.2(3)$ & $122.9(3)$ \\
Hickory & $101.9(6)$ & $87.9(6)$ & $89.1(6)$ & $107.2(5)$ \\
Red maple & $125.7(3)$ & $141.2(2)$ & $110.6(5)$ & $161.8(2)$ \\
Yellow-poplar & $143.0(2)$ & $97.61(5)$ & $119.4(2)$ & $76.1(6)$ \\
Mixed hardwoods & $151.8(1)$ & $209.0(1)$ & $146.6(1)$ & $170.8(1)$ \\
\hline
\end{tabular}

${ }^{1}$ Seedling crown volume was used in the calculation instead of basal area to determine relative dominance.

Fall and spring burns did little to change the dominance of oak and hickory species (Figure 3). Spring burns did create an increase in the dominance of oak and hickory in the regeneration layer, but also a much greater increase in the dominance of red maple. Red maple displayed the largest increase in importance after spring burns compared to other species. In fact, spring burns caused an increase in the relative dominance of all species groups, except for yellow-poplar.

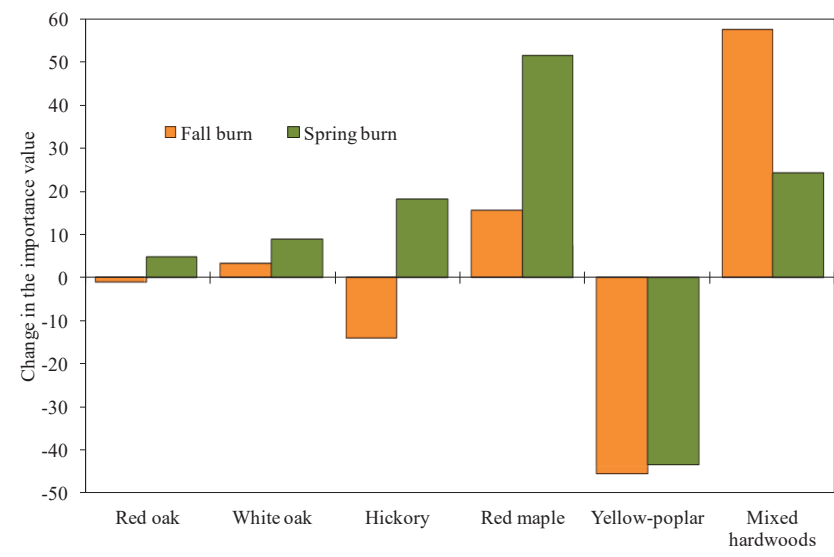

Figure 3. The change in magnitude of the Importance Value Index for selected species groups of large seedlings (0.3-1.3 m total height) after fall and spring burns in Richland Furnace and Zaleski State Forests located in southern Ohio. Seedling crown volume was used in the calculation instead of basal area to determine relative dominance. 
Fall burns had a more mixed effect, reducing the dominance of red oak, hickory and yellow-poplar and increasing the dominance of white oak, red maple and mixed hardwoods (Figure 3). Fall burns caused the greatest increase in dominance for mixed hardwoods, and the greatest decrease in the dominance of yellow-poplar.

\section{Discussion}

The time of year a burn is executed can result in different responses by a species. When the fall burns were executed (November), rootstocks contained higher carbohydrate reserves compared to diminished reserves during spring burns (Hodgkins, 1958; Ferguson, 1961; Brose \& Van Lear, 1998). In addition, cell activity, including the cambium, diminishes or becomes dormant by late fall. This combination allows seedlings to better withstand fall fires and respond more positively to growth in the spring (Drewa et al., 2002). Conversely, in the spring the carbohydrate reserves have begun to migrate out of the rootstocks and cells become more active, making seedlings more vulnerable (Hodgkins, 1958; Langdon, 1981; Garrison, 1972; Hough, 1968; Volland \& Dell, 1981; Bond \& van Wilgen, 1996; DeBano et al., 1998). Rootstocks are also more likely to survive fire when seedlings are dormant (Cain \& Shelton, 2000).

Oak species as a whole tend to be less susceptible to fire during the dormant season, such as late fall or early winter burns (Rouse, 1986; Rundel, 1980). In our study we found that spring burns appeared to be more detrimental to red oak than fall burns, although we found no significant difference. Red oak displayed greater reductions in canopy volume and stem numbers after spring burns compared to fall burns. Van Lear \& Waldrop (1988) reported that a spring fire killed $58 \%$ of existing red oak seedlings, and failed to increase oak abundance in the understory. North- ern red oak seedlings are easily killed by prescribed fires and only the larger stems will sprout and survive, even if their tops are killed (Johnson, 1974). Spring burns occur about the time of red oak germination, and thus recruitment of new individuals could be somewhat challenging.

Fall burns, on the other hand, seemed to have only a slightly more positive effect on white oak. Compared to spring burns, there was an increase in the seedling canopy volume while spring burns resulted in a slight reduction. Both fall and spring burns created a small increase in the number of regenerating white oak stems. The white oak species tended to outperform the red oak species with respect to establishment of post-fire regenerating stems, seedling canopy and IVI, although the differences were marginal. This seems to be consistent with Fan et al. (2012) in their study of repeated burns in upland oak-hickory forests in Missouri. While white oak gained in its dominance based on IVI in the large seedling layer after fall and spring fires, red oak lost some dominance after spring burns. However, the change in IVI was never large enough for either white or red oak to change in their dominance relative to other species.

However, based on IVI, spring burns had more of a positive impact on large seedlings than fall burns. All species, with the exception of yellow-poplar, experienced an increase in importance, or relative dominance. This may be in part a result of mixed hardwoods not experiencing as large of an increase in dominance as it did after fall burns, and the large decrease in IVI that yellow-poplar experienced. The canopy volume and stem number increase of mixed hardwoods after spring burns was much lower than after fall burns, and the reduction in the seedling canopy volume of yellow-poplar was greater after spring burns.

While mixed hardwoods were represented by many different species, sassafras (Sassafras albidum (Nutt.) Nees) and black- 
gum (Nyssa sylvatica Marsh.) tended to dominate this component of the regeneration layer. While both fall and spring burns increased the number and canopy volume of large mixed hardwood seedlings, fall burns produced higher amounts compared to spring burns. Both sassafras and blackgum respond positively to fire (Iverson et al., 2008). Sassafras sprouts prolifically after top-killed by fire (Cole et al., 1990) and also displays lower mortality rates after fire compared to that of other hardwoods (Apfelbaum \& Haney, 1990). Season of burn does not appear to have as much of a discriminatory effect on sassafras as it does on many other hardwoods (de Bruyn \& Buckner, 1981). Blackgum likewise sprouts prolifically after top-killed by fire (Keetch, 1944), and eventually succumbs to fire only after repeated burns (Waldrop et al., 1987).

Both fall and spring burns resulted in an increase in the seedling canopy volume and stems per hectare for red maple. Red maple experienced the greatest increase in canopy volume and stems per hectare after spring burns. While we did not record whether a stem was of sprout origin or not, it is probable that the majority of stems in the large seedling size category was of sprout origin, either from top-killed seedlings or as sprouts from stumps produced during the shelterwood harvest. Red maple can sprout vigorously after fire when seedlings are top-killed, including those growing as sprouts from cut stumps (Scheiner et al., 1988; Swan, 1970; Walters \& Yawney, 1990). Even though it is likely our sample size did not allow us to detect significant changes, the number of red maple stems increased by $76 \%$ and by $98 \%$ after fall and spring burns, respectively. The regrowth of red maple after fire can be rapid, and combined with its prolific sprouting ability, can create a high stem density that promulgates its dominance in a stand (Martin, 1955; Tirmenstein, 1991; Hutnick \& Yawney, 1961). While it is possible for prescribed fire to reduce the number of regenerating red maple stems, particular- ly fires of moderate intensity, those that do survive tend to show greater height growth after fire than oak seedlings (Green et al., 2010), thereby producing a larger number of large seedlings and increasing the seedling canopy. Even though Brose \& Van Lear (1998) found that spring and summer fires reduced the densities of red maple more than winter burns, we found no significant differences between burn seasons, and we discovered that red maple density increased in both cases. The reports of the effects of fire on red maple have been variable, with some reporting reduced densities (Reich et al., 1990; Elliott et al., 1999), while others report increased densities (Blankenship \& Arthur, 2006).

In comparison to the oak species, both fall and spring burns increased the competitiveness of red maple and the mixed hardwoods. If we look at the seedling canopy, we find that the ratio of the oak seedling canopy to the red maple seedling canopy dropped from 1.18 before fall burns to 0.61 after fall burns. After spring burns, the ratio has a greater reduction, dropping from 1.93 before burns to 0.47 after burns. In both cases the combined oak seedling canopy volume was greater than that of red maple seedling canopy before the burns, thereby suggesting that oak species were in a competitive position in comparison to red maple prior to burning.

On the spring burn sites, the oak canopy volume was almost equal to that of the mixed hardwoods, and a little more than half of the mixed hardwoods on the fall burn sites. The ratio of the oak seedling canopy to the mixed hardwood canopy prior to spring and fall burns was 1.07 and 0.59 , respectively. These ratios dropped to 0.47 and 0.19 after spring and fall burns, respectively.

While both red maple and oak will resprout after fire, their responses are physiologically different. Oak seedlings put more carbon and energy into storage and roots while red maple directs more of this energy into height growth (Brose \& Van 
Lear, 1998, 2004; Huddle \& Pallardy, 1999; Reich et al., 1990). This difference in energy allocation enables oak to survive repeated fires, but enables red maple to maintain height growth advantage over oak after repeated fires (Green et al., 2010). Hence, we found that the red maple seedling canopy was dominant over oak after both fall and spring burns, second only to the mixed hardwood group. When a disturbance occurs that increases the understory light, such as after shelterwood harvests and prescribed fire, red maple will produce new leaves rapidly as a response since they are thin with few secondary compounds (Nagel et al., 2002). However, repeated burns have demonstrated to reduce red maple density (Blankenship \& Arthur, 2006) while at the same time, frequent repeated burns have shown not to increase oak regeneration consistently (Hutchinson et al., 2005).

Both fall and spring burns reduced the number of large yellow-poplar seedlings and the seedling canopy. Yellow-poplar seedlings and saplings have thin bark which makes them very susceptible to fire damage, and fire generally kills young trees less than $2.5 \mathrm{~cm}$ in diameter (Beck, 1990). However, yellow-poplar seedlings can sprout from the root crown if topkilled by fire (Kelty, 1988). Nevertheless, mortality rates of large seedlings were higher than regenerative rates, and fall burns caused these mortality rates to be slightly higher. Accordingly, the ratio of the oak seedling canopy volume to that of yellow-poplar increased after both fall and spring burns. After fall burns the ratio increased from 0.75 to 1.83 and after spring burns increased from 1.01 to 2.91 . Both burns decreased any competitive advantage that yellow-poplar had over oak, reducing not only the canopy volume but also the number of regenerating stems. It has been reported that regardless of fire season, yellow-poplar densities are decreased as a result of fire.

Hickory was present in the regeneration layer prior to fall and spring in rela- tively few numbers, and its dominant position based on IVI was last prior to both fall and spring burns. After fall burns, the hickory IVI value dropped from 101.91 to 87.91, keeping it the least dominant of the six species groups studied. Fall burns not only decreased the number of regenerating stems but also the volume of the seedling canopy. Spring burns likewise reduced the number of regenerating hickory stems, but increased the seedling canopy volume. Accordingly, after spring burns the hickory IVI increased from 89.10 to 107.16, making it next to last after yellow-poplar.

Even though oak did not display a significant positive response to fire, it may be the response of its competitors that eventually cause the restoration of these oak systems to occur. The change in the composition and structure of eastern deciduous forests, and oak-dominated forests in particular, have been linked to long periods of fire suppression as well as the loss of the American chestnut (Castanea dentata (Marsh.) Borkh.) and changes in harvesting methods (Blankenship \& Arthur, 2006). Consequently, it is unlikely that a single burn after a shelterwood harvest will bring the forest back to its natural composition and structure. Reintroducing fire into these systems at a higher than normal periodicity may be what is necessary to restore these systems. Studies have demonstrated mixed results of fire on oak regeneration (Fan et al., 2012) and continued research is necessary to further understand the role of fire and other disturbances in these ecosystems, and how they can be used in management and restoration efforts.

\section{Conclusions}

Three years after a shelterwood harvest the effects of fall and spring burns on large hardwood seedlings were evaluated by examining the seedling canopy volume and the number of stems per hectare. Based on these evaluations, our study reveals that if 
regenerating oak and putting it into a competitive position in the regeneration layer is a management objective, then it will require more stand treatments than a single fire following a shelterwood harvest. Red maple and mixed hardwoods dominated the large seedling layer after both fall and spring burns based on the number of regenerating large seedlings and their total crown volumes. We did not detect any significant advantage that a single fall or spring burn created for oak.

Fall and spring burns appeared to be more deleterious to red oak than white oak. Red oak experienced reductions in numbers and canopy volume after spring burns, and canopy reductions after fall burns. There was only a marginal increase in red oak numbers after fall burns. White oak experienced small increases in the numbers of stems after both fall and spring burns, and an increase in the canopy volume after fall burns, but a slight decrease after spring burns. Yellow-poplar, a major oak competitor prior to fire, experienced dramatic reductions in the number of regenerating stems and canopy volume.

The fact that there were no dramatic changes in oak after fire compared to other species could become an advantage for oak in the future. The oak population remained relatively stable after both fall and spring burns, while other species, including red maple and yellow-poplar, experienced dramatic shifts. Yellow-poplar displayed high mortality after one burn, and it is likely that repeated burns will continue to keep this species at bay. Red maple on the other hand appeared to benefit from these burns.

Acknowledgements. The authors wish to acknowledge Marne Tichenell, Alex Silvis and Michael Hall for their assistance in the field and with data entry. Funds for this project were provided by the McIntireStennis Act of 1962 (P.L. 87-788), the Fundamental Research Funds for the Central Universities (China, 2572015CB05) and by a grant from the Ohio Division of Wildlife, Ohio Department of Natural Resources.

Conflicts of Interest. The authors wish to acknowledge that they have no affiliations with or involvement in any organization or entity with any financial interest or non-financial interest in the subject matter or materials discussed in this manuscript.

\section{References}

Abrams M.D. 1992. Fire and the development of oak forests. - BioScience, 42, 346-353.

Abrams, M.D., Downs, J.A. 1990. Successional replacement of old-growth white oak by mixed mesophytic hardwoods in southwestern Pennsylvania. - Canadian Journal of Forest Research, 20, 1864-1870. https://doi. org/10.1139/ x90-250.

Apfelbaum, S.I., Haney, A. 1990. Management of degraded oak savanna remnants in the upper Midwest: Preliminary results from three years of study. - Hughes, H.G., Bonnicksen, T.M. (eds.). Restoration '89: The New Management Challenge: Proceedings, 1st Annual Meeting of the Society for Ecological Restoration, Jan 1989. Oakland, CA. Madison, WI: The University of Wisconsin Arboretum, 280-291.

Avina, M.M., Williams, R.A., Gehrt, S.D. 2007. A method of quantifying forest vertical structure for the purpose of evaluating bat habitat. - Buckley, D.S., Clatterbuck, W.K. (eds.). Proceedings of the 15th Central Hardwood Forest Conference. e-Gen. - Technical Report SRS-101. U.S. Department of Agriculture, Forest Service, Southern Research Station, 355-363.

Beck, D.E. 1990. Liriodendron tulipifera L. yellow poplar. - Burns, R.M., Honkala, B.H. (tech. coords.). Silvics of North America: 2. Hardwoods. Washington, DC, U.S. Department of Agriculture, Forest Service, 406-416.

Blankenship, B.A., Arthur, M.A. 2006. Stand structure over 9 years in burned and fireexcluded oak stands on the Cumberland Plateau, Kentucky. - Forest Ecology and Management, 225, 134-145. https://doi. org/10.1016/j.foreco.2005.12.032.

Bond, W.J., van Wilgen, B.W. 1996. Fire and Plants. London, Chapman and Hall. 272 p.

Bradstock, R.A., Cohn, J.S. 2002. Demographic characteristics of mallee pine (Callitris verrucosa) in fire-prone mallee communities of central New South Wales. - Australian Journal of Botany, 50, 653-665. 
Brose, P.H., Van Lear, D.H. 1998. Responses of hardwood advance regeneration to seasonal prescribed fires in oak-dominated shelterwood stands. - Canadian Journal of Forest Research, 28, 331-339.

Brose, P.H., Van Lear, D.H. 2004. Survival of hardwood regeneration during prescribed fires: The importance of root development and root collar location. - General Technical Report SRS-73. Asheville, NC, USDA Forest Service, Southern Research Station, 123-127.

Brose, P.H., Van Lear, D.H., Cooper, R. 1999. Using shelterwood harvests and prescribed fire to regenerate oak stands on productive upland sites. - Forest Ecology and Management, 113, 125-141.

Cain, M.D., Shelton, M.G. 2000. Survival and growth of Pinus echinata and Quercus seedlings in response to simulated summer and winter prescribed burns. - Canadian Journal of Forest Research, 30, 1830-1836.

Cole, K.L., Benjamin, P.K., Klick, K.F. 1990. The effects of prescribed burning on oak woods and prairies in the Indiana Dunes. - Restoration \& Management Notes, 8, 37-38.

Curtis, J.T. 1959. The Vegetation of Wisconsin: An Ordination of Plant Communities. Madison, University of Wisconsin Press. 657 pp.

D'Antonio, C.M., Hughes, F.R., Vitousek, P.M. 2001. Factors influencing dynamics of two invasive C4 grasses in seasonally dry Hawaii woodlands. - Ecology, 82, 89-104. https:/ / doi. org/10.1890/0012-9658(2001)082[0089:FIDOT I]2.0.CO;2.

DeBano, L.F., Neary, D.G., Ffolliott, P.F. 1998. Fire Effects on Ecosystems. New York, John Wiley \& Sons. 333 pp.

de Bruyn, P., Buckner, E. 1981. Prescribed fire on sloping terrain in west Tennessee to maintain loblolly pine (Pinus taeda). - Barnett, J.P. (ed.). Proceedings, 1st Biennial Southern Silvicultural Research Conference, Nov. 1980. - General Technical Report SO-34. New Orleans, LA, U.S. Department of Agriculture, Forest Service, Southern Forest Experiment Station, 67-69.

Delcourt, P.A., Delcourt, H.R. 1987. Long-Term Forest Dynamics of the Temperate Zone. New York, Springer. 439 pp.

Drewa, P.B., Platt, W.J., Moser, E.B. 2002. Fire effects on resprouting of shrubs in headwaters of southeastern longleaf pine savannas. Ecology, 83, 755-767.

Elliott, K.J., L. Hendrick, R., Major, A.E., Vose, J.M., Swank, W.T. 1999. Vegetation dynamics after a prescribed fire in the southern Appalachians. - Forest Ecology and Management, 114, 199-213. https://doi.org/10.1016/S03781127(98)00351-X.
Fan, Z., Ma, Z., Dey, D.C., Roberts, S.D. 2012. Response of advance reproduction of oaks and associated species to repeated prescribed fires in upland oak-hickory forests, Missouri. Forest Ecology and Management, 266, 160-169. https://doi.org/10.1016/j.foreco.2011.08.034.

Ferguson, E.R. 1961. Effects of prescribed fires on understory stems in pine-hardwood stands of Texas. - Journal of Forestry, 59, 356-359.

Garrison, G.A. 1972. Carbohydrate reserves and response to use. - McKell, C.M., Blaisdell, J.P., Goodin, J.R. (eds.). Wildland Shrubs Their Biology and Utilization. Proceedings of a Symposium. - General Technical Report GTRINT-1. Ogden, UT, U.S. Department of Agriculture, Forest Service, Intermountain Forest and Range Experiment Station, 271-278.

Glasgow, L.S., Matlack, G.R. 2007. Glasgow, L.S., Matlack, G.R., 2007. The effects of prescribed burning and canopy openness on establishment of two non-native plant species in a deciduous forest, southeast Ohio, USA. Forest Ecology and Management, 238, 319-329. https://doi.org/10.1016/j.foreco.2006.10.025.

Green, S.R., Arthur, M.A., Blankenship, B.A. 2010. Oak and red maple seedling survival and growth following periodic prescribed fire on xeric ridgetops on the Cumberland Plateau. - Forest Ecology and Management, 259, 2256-2266. https://doi.org/10.1016/j. foreco.2010.02.026.

Hodgkins, E.J. 1958. Effects of fire on undergrowth vegetation in upland southern pine forests. - Ecology, 39, 36-46. https://doi. org/10.2307/1929965.

Hodgkinson, K.C. 1991. Shrub recruitment response to intensity and season of fire in semiarid woodland. - Journal of Applied Ecology, 28, 60-70. https://doi.org/10.2307/2404113.

Hoffmann, W.A. 1996. The effects of fire and cover on seedling establishment in a neotropical savanna. - Journal of Ecology, 84, 383-393.

Huddle, J.A., Pallardy, S.G. 1999. Effect of fire on survival and growth of Acer rubrum and Quercus seedlings. - Forest Ecology and Management, 118, 49-56. https://doi. org/10.1016/S0378-1127(98)00485-X.

Hutchinson, T.F., Sutherland, E.K., Yaussy, D.A. 2005. Effects of repeated prescribed fires on the structure, composition, and regeneration of mixed-oak forests in Ohio. - Forest Ecology and Management, 218, 210- 228. https://doi. org/10.1016/j.foreco.2005.07.011.

Hough, W.A. 1968. Carbohydrate reserves of sawpalmetto: seasonal variation and effects of burning. - Forest Science, 14, 399-405.

Hutnick, R.J., Yawney, H.W. 1961. Silvical characteristics of red maple (Acer rubrum). Station Paper NE-142. Upper Darby, PA, U.S. Department of Agriculture, Forest Service, Northeastern Forest Experiment Station. 18 pp. 
Iverson, L.R., Hutchinson, T.F., Prasad, A.M., Peters, M.P. 2008. Thinning, fire, and oak regeneration across a heterogeneous landscape in the eastern U.S.: 7-year results. - Forest Ecology and Management, 255, 3035-3050. https://doi.org/10.1016/j.foreco.2007.09.088.

Johnson, P.S. 1974. Survival and growth of northern red oak seedlings following a prescribed burn. - Research Note NC-177. St. Paul, MN, U.S. Deptartment of Agriculture, Forest Service, North Central Forest Experiment Station. 3 pp.

Karlik, J.F., McKay, A.H. 2002. Leaf area index, leaf mass density, and allometric relationships derived from harvest of blue oaks in a California oak savanna. - Standiford, R.B. et al. (tech. eds.). Proceedings of the Fifth Symposium on Oak Woodlands: Oaks in California's Challenging Landscape. - General Technical Report PSW-GTR-184. Albany, CA, U.S. Department of Agriculture, Forest Service, Pacific Southwest Research Station, 719-729.

Keetch, J.J. 1944. Sprout development on onceburned and repeatedly-burned areas in the southern Appalachians. - Technical Note No. 59. Asheville, NC, U.S. Department of Agriculture, Forest Service, Appalachian Forest Experiment Station. 3 pp.

Kelty, M.J. 1988. Sources of hardwood regeneration and factors that influence these sources. - Smith, H.C., Perkey, A.W., Kidd, W.E., Jr. (eds.). Proceedings: Guidelines for Regenerating Appalachian Hardwood Stands. Morgantown, WV, West Virginia University Books, 17-30.

Knox, K.J.E., Clarke, P.J. 2006. Fire season and intensity affect shrub recruitment in temperate sclerophyllous woodlands. - Oecologia, 149, 730-739. https:/ / doi.org/10.1007/s00442-0060480-6.

Konstantinidis, P., Tsiourlis, G., Galatsidas, S. 2005. Effects of wildfire season on the resprouting of kermes oak (Quercus coccifera L.). - Forest Ecology and Management, 208, 15-27. https:/ / doi.org/10.1016/j.foreco.2004.09.021.

Langdon, O.G. 1981. Some effects of prescribed fire on understory vegetation in loblolly pine stands. - Wood, G.W. (ed.). Proceedings, Prescribed Fire and Wildlife in Southern Forests. Clemson, SC, Clemson University, 143-153.

Loftis, D.L., McGee, C.E. (eds.). 1993. Oak Regeneration: serious problems, practical recommendations. - General Technical Report SE-84. Asheville, NC, U.S. Department of Agriculture, Forest Service, Southeastern Research Station, 8-10.

Lorimer, C.G. 1993. Causes of the oak regeneration problem. - Loftis, D.L., McGee, C.E. (eds.). Oak Regeneration: Serious Problems, Practical Recommendations. - General Technical Report SE-84. Asheville, NC, U.S. Department of Agriculture, Forest Service, Southeastern Forest Experiment Station, 14-39.
Lorimer, C.G., Chapman, J.W., Lambert, W.D. 1994. Tall understory vegetation as a factor in the poor development of oak seedlings beneath mature stands. - Journal of Ecology, $82,227-237$

Martin, J.L. 1955. Observations on the origin and early development of a plant community following a forest fire. - The Forestry Chronicle, 31, 154-161.https:// doi.org/10.5558/tfc311542.

McShea, W.J., Healy, W.M. 2002. Oak Forest Ecosystems: Ecology and Management for Wildlife. Baltimore, Johns Hopkins University Press. 448 pp.

Nagel, J.M., Griffin, K.L., Schuster, W.S.F., Tissue, D.T., Turnbull, M.H., Brown, K.J., Whitehead, D. 2002. Energy investment in leaves of red maple and co-occurring oaks within a forested watershed. - Tree Physiology, 22, 859-867. https://doi.org/10.1093/treephys/22.12.859.

Reich, P.B., Abrams, M.D., Ellsworth, D.S., Kruger, E.L., Tabone, T.J. 1990. Fire affects ecophysiology and community dynamics of central Wisconsin oak forest regeneration. - Ecology, 71, 2179-2190. https://doi. org/10.2307/1938631.

Rouse, C. 1986. Fire effects in northeastern forests: oak. - General Technical Report NC-105. St. Paul, MN, U.S. Department of Agriculture, Forest Service, North Central Forest Experiment Station. 7 pp.

Rundel, P.W. 1980. Adaptations of Mediterraneanclimate oaks to environmental stress. Plumb, T.R. (tech. cord.). Proceedings of the Symposium on the Ecology, Management and Utilization of California Oaks. - General Technical Report PSW-44. Berkeley, CA, U.S. Department of Agriculture, Forest Service, Pacific Southwest Forest and Range Experiment Station, 43-54.

Scheiner, S.M., Sharik, T.L., Roberts, M.R., Vande Kopple, R. 1988. Tree density and modes of tree recruitment in a Michigan pine-hardwood forest after clear-cutting and burning. - The Canadian Field-Naturalist, 102, 634-638.

Sparks, J.C., Masters, R.E., Engle, D.M., Palmer, M.W., Bukenhofer, G.A. 1998. Effects of late growing-season and late dormant-season prescribed fire on herbaceous vegetation in restored pine-grassland communities. Journal of Vegetation Science, 9, 133-142. https://doi.org/10.2307/3237231.

Steinhoff, R.J. 1978. Distribution, ecology, silvicultural characteristics, and genetics of the Abies grandis-Abies concolor complex. Proceedings of the IUFRO Joint Meeting of Working Parties: Vol. 1-Background Papers and Douglas-Fir Provinces. Vancouver, BC, British Columbia Ministry of Forestry, 123132.

Swan, Jr. F.R. 1970. Post-fire response of four plant communities in south-central New York state. - Ecology, 51, 1074-1082. https://doi. org/10.2307/1933636. 
Tirmenstein, D.A. 1991. Acer rubrum. - Fire Effects Information System. U.S. Department of Agriculture, Forest Service, Rocky Mountain Research Station, Fire Sciences Laboratory (Producer). [WWW document]. - URL http:/ / www.fs.fed.us/database/feis/. [Accessed 4 September 2017].

Van Lear, D.H., Brose, P.H. 2002. Fire and oak management. - McShea, W.J., Healy, W.M. (eds.). Oak Forest Ecosystems. Baltimore, Maryland, USA, Johns Hopkins University Press, 269-279.

Van Lear, D.H., Waldrop, T.A. 1988. Effects of fire on natural regeneration in the Appalachian Mountains. - Clay Smith, H., Perkey, A.W., Kidd, W.E. Jr. (eds.). Guidelines for Regenerating Appalachian Hardwood Stands: Workshop Proceedings. Morgantown, WV, West Virginia University Books, 56-70.
Volland, L.A., Dell, J.D. 1981. Fire effects on Pacific Northwest forest and range vegetation. - Report R6-RM067. Portland, OR, U.S. Department of Agriculture, Forest Service, Pacific Northwest Region. 23 pp.

Waldrop, T.A., Van Lear, D.H., Lloyd, F.T., Harms, W.R. 1987. Long-term studies of prescribed burning in loblolly pine forests of the Southeastern Coastal Plain. - General Technical Report SE-45. Asheville, NC, U.S. Department of Agriculture, Forest Service, Southeastern Forest Experiment Station. 23 pp.

Walters, R.S., Yawney, H.W. 1990. Acer rubrum L. red maple. - Burns, R.M., Honkala, B.H. (tech. coords.). Silvics of North America: 2. Hardwoods. Washington, DC: U.S. Department of Agriculture, Forest Service, 60-69.

Williams, R.A. 2003. Use of stand density index as an alternative to stocking percent in upland hardwoods. - Northern Journal of Applied Forestry, 20, 1-6. 